\title{
ANALYSIS OF SPRING WATER AND STRATEGIES TO MAKE THEM SUSTAINABLE IN ORDER TO DEVELOP WELLNESS AND SPA TOURISM IN PARTS OF HIMALAYA
}

\author{
Garima Dubey ${ }^{1}$, Gauhar Mahmood ${ }^{2}$ and Amina Zakiah ${ }^{3}$ \\ ${ }^{* 1}$ Architect-Landscape Architect, New Delhi, India \\ ${ }^{2}$ Department of Civil Engineering, Jamia Millia Islamia, New Delhi, India \\ ${ }^{3}$ Environment Management Consultant, New Delhi, India \\ ${ }^{*}$ Correspondence Author email: garimadubey90@yahoo.in
}

How to cite this paper:

Dubey, Garima; Mahmood, Gauhar and Zakiah, Amina (2021) Analysis of spring water and strategies to make them sustainable in order to develop wellness and spa tourism in parts of Himalaya, Journal of Global Resources, Vol. 07 (02)

DOI:

10.46587/JGR.2021.v07i02.007

Received: 21 March 2021 Reviewed: 10 April 2021

Revised: 11 May 2021

Final Accepted: 23 May 2021

\section{OPEN A C C ESS}

Freely available Online www.isdesr.org

\begin{abstract}
The therapeutic Himalayan Spring water has application in Indian yoga practices and hydrotherapy for curing various deadly diseases. Seeing this as a great potential, many stakeholders are investing in the development of wellness tourism with other premium services in the Himalayan region. Thousands of tourists from around the globe are ready to spend a sizeable amount of money on a single-night stay on these yoga ashrams and resorts for their wellness. The paper attempts to identify the potential locations for developing wellness tourism based on spring water (like Badgam, Anantnag, Udhampur, Kathua, Kullu, Shimla, Mandi, Kangra, Uttarkashi, Tehri, Dehradun, Rudraprayag, Southern and western parts of Sikkim). The paper also discusses the possible design and development considerations that will attract more tourist's footfall without affecting the spring water quality and sensitive ecosystems of the Himalayan region. The footfall is at peak during July followed by months of April, June, September, October, May, and November whereas the spring discharge reduces 70-80 percent during summer months and hence there is a water shortage during this time. With the help of hydro landscape solutions, we can develop the spring water on sustainable grounds which will ensure an optimum supply of this water to help tourism grow. The study and its findings are helpful for architects, planners, administration, water supply authorities, yogic ashrams, resorts, etc.
\end{abstract}

Keywords: Himalayan Spring Water, Hydrogeology, Sustainability, Wellness Tourism 


\section{Introduction}

The great Indian Himalayas also known as the water tower of India has its importance in generating and contributing to the 10 largest river systems in Asia. The unique geological feature and varying topography are responsible for groundwater movement and aquifer recharge which consequently contributes to the drainage systems of this region. The spring water obtained from glacial melt and rainfall oozes out of fracture and joints of these rugged mountains is the purest form of water on earth. This spring water is not only a dependable source and supporting life systems in the Himalayan region but also is popular for its therapeutical properties. The quality of this water is so pure that many industries are directly selling this as packaged drinking water with a negligible cost for purification. Moreover, the spring water in this region is rich in minerals and several beneficial micro-organisms which are beneficial for health.

Not only the spring water is sacred from a religious and cultural point of view, but also people from all over the world believe in its healing properties and wonders it does to their health even treating many incurable diseases like cancer, arthritis, abdominal disorders, etc. The Himalayan region also filled with various pilgrimage sites which have equal potential to develop tourism based on spring water and providing an ashram-based lifestyle experience to the visitors. There are several sulphur springs in the Mandi region along the Sutlej river, having the ability to cure bones and joint-related problems. Moreover, due to less urbanization and pollution, the climatic conditions together with the air quality is so pure that people who have spent even 10 to 15 days living in the Himalayan region reported that they were able to control their blood pressure and other health problems.

Many investors see this region as a potential to develop and promote activities like health resorts, yoga ashrams, and wellness spa centres. With the other favourable conditions like climate, air quality, beautiful landscapes, spring water, herbal vegetation people are ready to spend premium prices to get health benefits from this region. Additionally, these resorts will also provide a leisure experience for the tourist who is willing to come for a business meeting and avoid highly polluted cities like Delhi, Chandigarh, Gurgaon, Noida, etc.

The areas like Sukhnag, Anantnag, Verinag, Hazratbal, Udhampur, Kathua in Jammu and Kashmir region, Kullu, Manali, Manikaran, Kasol, Vashishta, Shimla, Mandi, Kangra in Himachal Pradesh, Uttarkashi, Syansu, Nandgaon, Bugdi khala, Neel garh, Dhaulagiri, Rishikesh, Dehradun, Mussoorie, Rudraprayag, Gaurikund in Uttarakhand, southern and western parts of Sikkim have good discharge potential to supply enough quantities of this spring water to develop tourism. However, the water can be scarce during the dry seasons of the year i.e., from March to June. With the help of hydro landscape solutions, this water can be made sustainable to fulfil the desired requirement.

\section{Study Area}

The Indian Himalayan region spreads over an area of 5,33,000sqkm lying between latitudes $26^{\circ} 20^{\prime}$ and $35^{\circ} 40^{\prime}$ North and between latitudes $75^{\circ} 50^{\prime}$ and $95^{\circ} 40^{\prime}$ East. It covers the Indian states of Jammu and Kashmir, Uttarakhand and Himachal Pradesh in the North, Sikkim, Arunachal Pradesh, Meghalaya, Manipur, Mizoram, Nagaland and Tripura in the North-East along with the hilly districts of Dima, Hasao and Karhi, Anglolng in Assam region and Darjeeling, Kalimpong in West Bengal. The physiographically and litho-structurally, there are four distinctive terranes of the Himalayas: (Valdiya 2010) (Rao n.d.)

a. The Siwalik: The elevation of this region is below $900 \mathrm{~m}$ and composed of unconsolidated sedimentary rocks that are deposited in a lake formed after plate collision. This part is fossiliferous and is relatively bestow with water because of their 
partly consolidated form of sediments. The rocky and uneven Siwalik ranges are separated by south-facing cliffs whereas, northern cliffs form various cascades and waterfalls. The long flat rugged terrains are known as duns which represent gravelly deposits within depression or filling of dried lakes. The terrain is sparsely populated and is covered with dense forest.

b. Himachal or lesser Himalayas: these are non-fossiliferous ranges lying in the north of Siwalik. Comprise of Pir Panjal, Dhauladhar, Mussoorie, Nainital, Mahabharat ranges with elevation between $900 \mathrm{~m}-3000 \mathrm{~m}$ constitute slightly metamorphosed sedimentary rocks like slates, quartzites, limestones and phyllites. Towards Siwalik, these are highly rugged and thickly forested ranges. Northern part is lofty towards Kumaun and Nepal that stretches gentler terrains. The summits are rounded with gentler slopes and flowing streams in undulating stretches. The valleys of rivers like Ravi, Yamuna, Ganga, Kali, Gandaki, Satluj, Kosi, Arun and Subansiri forms deep gorges and defiles. It is comparatively densely populated part of the Himalayas. The terrane mostly consists of Precambrian rocks of 540 year and older age. The thick layer of metamorphic and granitic rocks covers sedimentary and volcanic rocks. The rocks are embedded in soil.

c. The Himadri or greater Himalayas: These are snow covered and rough peaks mostly comprises of sedimentary and metamorphic rocks along with igneous rocks (granites of different ages). These terranes face water shortages and are mostly depended on spring water. Elevation varies between $3000 \mathrm{~m}$ to $8000 \mathrm{~m}$. It covers Nanga parbat $(8126 \mathrm{~m})$, Nun-Kung $(7135 \mathrm{~m})$, Kedarnath $(6900 \mathrm{~m})$, Badrinath $(7138 \mathrm{~m})$, Nanda Devi(7817m), Dhaulagiri (8172m), Sagarmath (8848m), Kanchanjangha (8598m) and Namcha Barwa $(7756 \mathrm{~m})$. Its Southern face is divided by precipitous high cliffs whereas Northern part is steep slopes which forms cascade and high forced streams. The terrane consists of thick stack of high-grade metamorphic rocks and gneissic granite encroached by 40-20-million-year-old light-coloured granites.

d. Tethys Himalaya: the rugged Tethys Himalayan terrain lies after Himadri terranes. It is made up of sedimentary rocks of late Precambrain (greater than 600million year) to cretaceous and Eocene (95 to 45 million year) age. The region is sparsely vegetated. Himalaya province ends up against the zone where India joins with Asia and this area is characterized by deep faults and series of 60 - to 48-million-year-old volcanic islands.

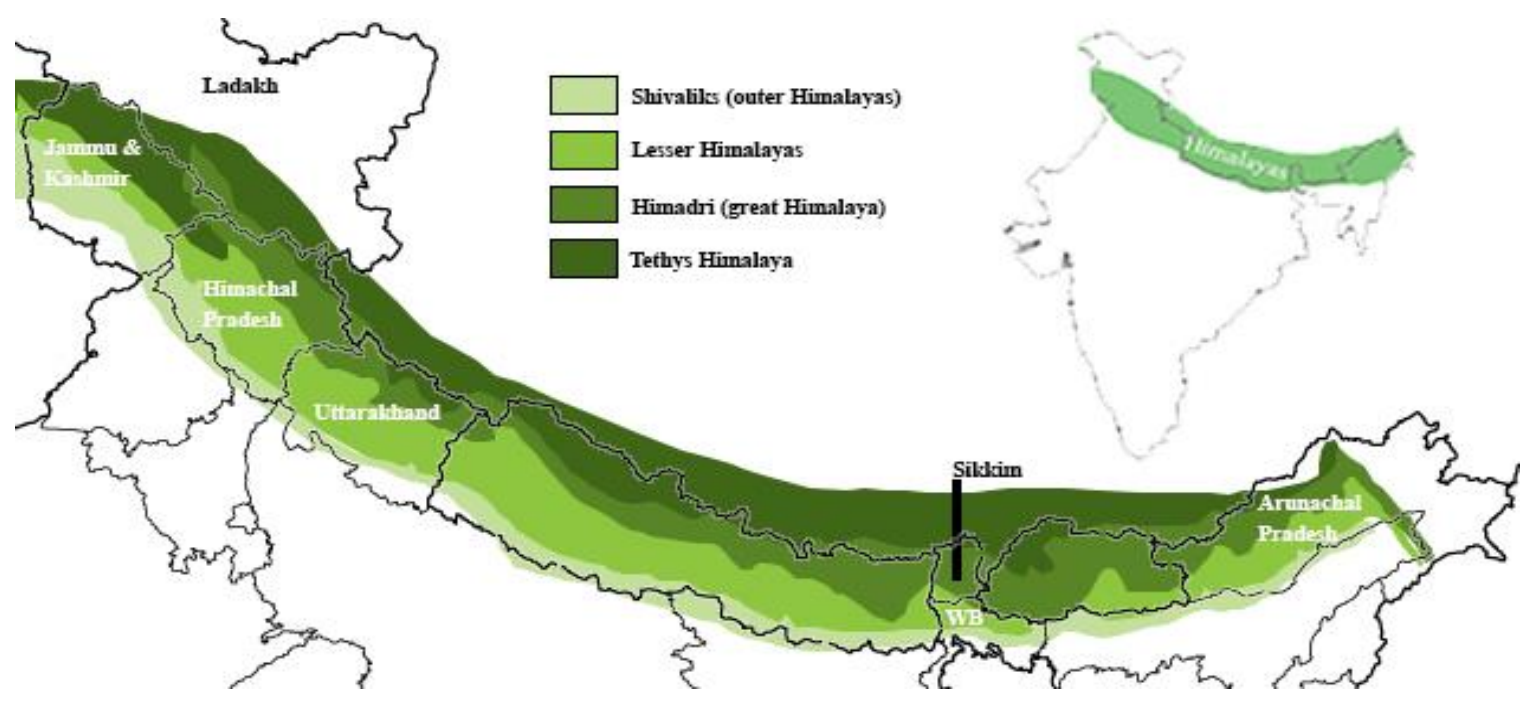

Figure 01: Expanse of Himalayas in India along with its physiographic and lithostructural divisions (Source: As per data from Valdiya, 2010) 


\section{Scope and Objectives of the Study}

There are various studies available on the health benefits of spring water, geothermal springs in wellness tourism in different parts of the world, and the importance of Himalayan spring water for sustaining life in the Himalaya. The potential areas for developing wellness tourism (in the Indian Himalayan region) which specifically involves Indian yoga practices, naturopathy, hydrotherapy and Ayurveda practices based on health benefits of spring water and its sustainable development have not been addressed in any research. This study aims at providing policies and suggestions for making spring water a sustainable source in developing wellness tourism in potential zones of the Himalayan region.

\section{Objectives}

a. To understand the process of spring formation in Himalayan region.

b. To understand the importance of spring water with special reference to its use in naturopathy, yoga and sowa-rigpa medicine.

c. To analyse the regional spring areas in parts of Himalayas and understand the water discharge capacity in different months in order to figure out lean period of water shortage.

d. To understand monthly footfall pattern of the tourist in this region.

e. To compare and analyse the water spring water quality in these regions.

f. To understand spring water tourism in other parts of the world and draw a comparison with Himalayan context.

g. To discuss planning and design strategies that can be considered while developing tourism in these areas.

h. Finally, to suggest hydro- landscape measure for the sustainable development of spring water to maintain supply throughout the year.

\section{METHODS AND MATERIAL}

\section{Methods of Data Collection and Analysis}

The Himalayan region has been selected for the study as it has got an enormous amount of spring water sources that are unutilized and the valuable water generally drains away in open and gets wasted. The birthplace of yoga, pollution-free environment, beautiful landscapes, and its spiritual importance makes it an excellent choice for developing health tourism. The data is mostly collected with the help of various online texts, books like geodynamic evolution by KS Valdiya, Geology of India by DN Wadia, and Geology of India by IM Ramakrishnan and R. Vaidyanadhan to understand the geology and process of spring formation in the Himalayan region. Research work on healing properties of spring water and its use in naturopathy and yoga. Central groundwater reports of various districts in the study area to understand the spring discharge along with the studies on rainfall and spring discharge capacity relationship. The tourist footfall pattern of Himachal Pradesh, Uttarakhand, and Sikkim was also understood using data from the Ministry of tourism. Research data for understanding spring water tourism all around the world was referred to draw a comparison and potential in the Himalayan region.

The above data and its analysis were useful in deriving planning and design strategies to develop wellness tourism with consideration to fragile Himalayan ecology and spring recharge zone. In the end, with the understanding of water demands in the lean period, strategies that can be adopted to make the spring water sustainable using hydro landscape solutions are discussed. 


\section{Formation of Springs in Himalayan Region}

Unconsolidated granular materials like gravels, cobbles, pebbles, and sand deposits are potential areas for water to flow and seep down. The ground water moves and get stored through synclinal folds, faults, joints, and stratified rocks. This groundwater is then discharged in the form of springs and seepages through fault lines, fractures, joints, and permeable layers. The groundwater collects in the valleys and can be found as a discontinuous local body like landslide-debris fans and cones, water or river terraces in perched aquifers (confined unconfined both) along with the areas of jointing, fracturing, and faulting. The areas with low steeps and flat grounds accompanying deeply weathered rocks are generally the areas of recharge and the areas with steep slopes, cliffs, and first and second-order stream at slope breaks are discharge areas. (Bhartarya 1989)

The glacier melt snow water and rainwater are the two main sources of aquifer recharge in this region. The glacial meltwater helps to recharge water in Himalayan water specially in the dry season which explains the perennial nature of Himalayan springs.

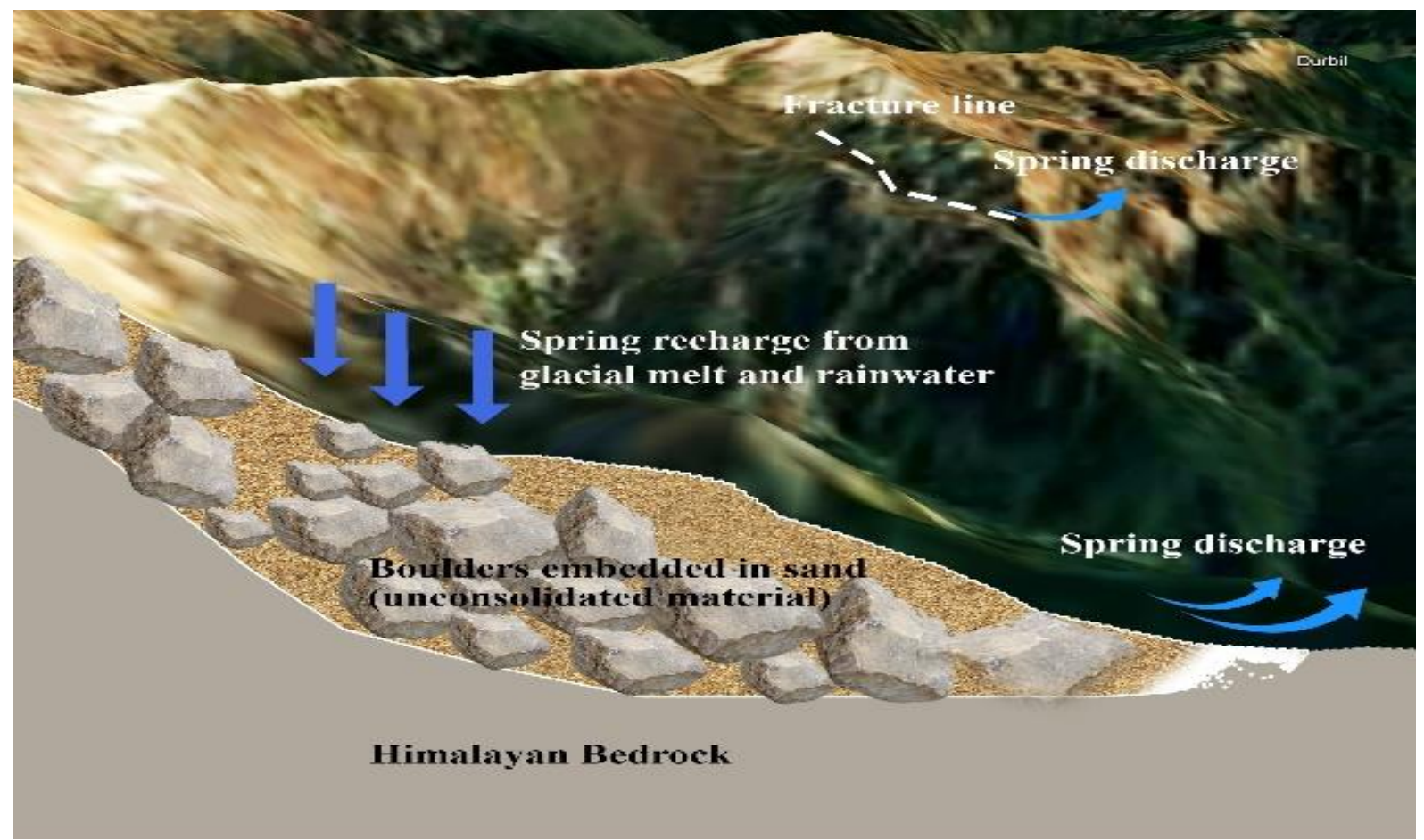

Figure 02: Formation of springs in Himalayan region (Source: Author generated)

\section{Importance of Himalayan Springs in Indian naturopathy, medicine and Ayurveda}

The spring water obtained from Himalayan region has great importance and application in naturopathy along with yogic activities. The geothermal hot springs in have mentioned their importance in Sowa-Rigpa medicine which was practiced in entire Trans- Himalayan region. Sowa-Rigpa meaning knowledge of healing is currently practiced in Himalayan regions like Ladakh, Lahoul, Spiti, parts of Himachal Pradesh, West Bengal, Sikkim, Arunachal Pradesh. This form of treatment is trusted by people more than they trust in modern medicine and is based on fundamental principles of Panchamahabutha (five big elements), Tridosha (three energies i.e., vata, pitta, kaph), Sapta Dhatu (seven body tissues), do's and don'ts, dietary guideline, pulse examination etc like Ayurveda.

Hydrotherapy which involves the use of spring water is used for the treatment of many diseases like headache, breast cancer, skin cancer, arthritis, indigestion etc. The water in 
these springs is rich in minerals like sulphur, germanium, boron, copper, chromium etc, which imparts it special healing properties. (mantralay n.d.) (Chauhan 2016)

\section{Analysis of Regional Spring Areas in Parts of Himalayas}

Table 01: Spring Potential in Himalayan Region for Tourism

\begin{tabular}{|c|c|c|c|c|}
\hline \# & Areas & Spring type & $\begin{array}{l}\text { Number of } \\
\text { springs }\end{array}$ & $\begin{array}{c}\text { Minimum and } \\
\text { Maximum Discharge } \\
\text { of springs (L/day) }\end{array}$ \\
\hline 1. & $\begin{array}{l}\text { Hazratbal and } \\
\text { Sukhnag } \\
\text { (Badgam district) }\end{array}$ & $\begin{array}{l}\text { Contact zones and } \\
\text { fractures in hilly areas }\end{array}$ & $\begin{array}{l}\text { More than } 30 \\
\text { locations }\end{array}$ & 8,640 to $2,00,67,264$ \\
\hline 2. & $\begin{array}{l}\text { Anantnag and } \\
\text { Verinag } \\
\text { (Anantnag) }\end{array}$ & $\begin{array}{l}\text { Contact zones and } \\
\text { fractures in hilly areas }\end{array}$ & $\begin{array}{c}8 \text { locations and } \\
\text { more }\end{array}$ & $4,32,000$ to $57,88,800$ \\
\hline 3. & Udhampur & $\begin{array}{l}\text { Along Fractured zone } \\
\text { and limestone } \\
\text { formation }\end{array}$ & $\begin{array}{l}\text { More than } 100 \\
\text { locations }\end{array}$ & $86,400-8,64,000$ \\
\hline 4. & Kathua & $\begin{array}{l}\text { Mostly along contact } \\
\text { zone and hilly areas }\end{array}$ & $\begin{array}{l}\text { More than } 20 \\
\text { locations }\end{array}$ & $43,200-10,02,240$ \\
\hline 5. & $\begin{array}{l}\text { Kullu, Manali, } \\
\text { Kasol, Vashisht } \\
\text { and Manikaran } \\
\text { (kullu district) }\end{array}$ & $\begin{array}{l}\text { Gravity springs by } \\
\text { contact formations }\end{array}$ & $\begin{array}{l}20 \text { and more } \\
\text { locations }\end{array}$ & $43,200-21,60,000$ \\
\hline 6. & Mandi district & $\begin{array}{l}\text { Fracture zones and } \\
\text { contact zone in hilly } \\
\text { areas }\end{array}$ & $\begin{array}{l}20 \text { and more } \\
\text { locations }\end{array}$ & $43,200-57,88,800$ \\
\hline 7. & Shimla district & $\begin{array}{l}\text { Gravity, contact and } \\
\text { fracture type }\end{array}$ & $\begin{array}{c}38 \text { and more } \\
\text { locations }\end{array}$ & $43,200-57,88,800$ \\
\hline \multirow[t]{2}{*}{8.} & Kangra district & $\begin{array}{l}\text { Fractures, faults and } \\
\text { thrust zones }\end{array}$ & - & $\begin{array}{c}86,400 \text { to } 34,56,000 \\
\text { and more } \\
\end{array}$ \\
\hline & Uttarakhand & & & \\
\hline 9. & $\begin{array}{l}\text { Uttarkashi } \\
\text { district }\end{array}$ & Fractures and fault & - & $2,592-2,76,480$ \\
\hline 10. & $\begin{array}{l}\text { Syansu, } \\
\text { Nandgaon, } \\
\text { (Tehri district) }\end{array}$ & $\begin{array}{l}\text { Joints and Fractured } \\
\text { type }\end{array}$ & 48 & $43,200-10,02,240$ \\
\hline 11. & $\begin{array}{l}\text { Rishikesh, } \\
\text { Mussourie, } \\
\text { Dehradun in } \\
\text { Dehradun district }\end{array}$ & $\begin{array}{l}\text { Gravitaty springs in } \\
\text { Shivalik region }\end{array}$ & More than 70 & $1,728-97,63,200$ \\
\hline \multirow[t]{2}{*}{12.} & $\begin{array}{l}\text { Rudraprayag, } \\
\text { Gaurikund, }\end{array}$ & $\begin{array}{l}\text { Gravity springs and } \\
\text { contact formation }\end{array}$ & 275 and more & $43,200-17,28,000$ \\
\hline & Sikkim & & & \\
\hline 13. & South Sikkim & Gravity springs & - & $11,520-1,87,200$ \\
\hline 14. & East Sikkim & Fractured zones & - & $21,600-1,55,520$ \\
\hline
\end{tabular}

Source: Central Ground Water Board, Himalayan Region 


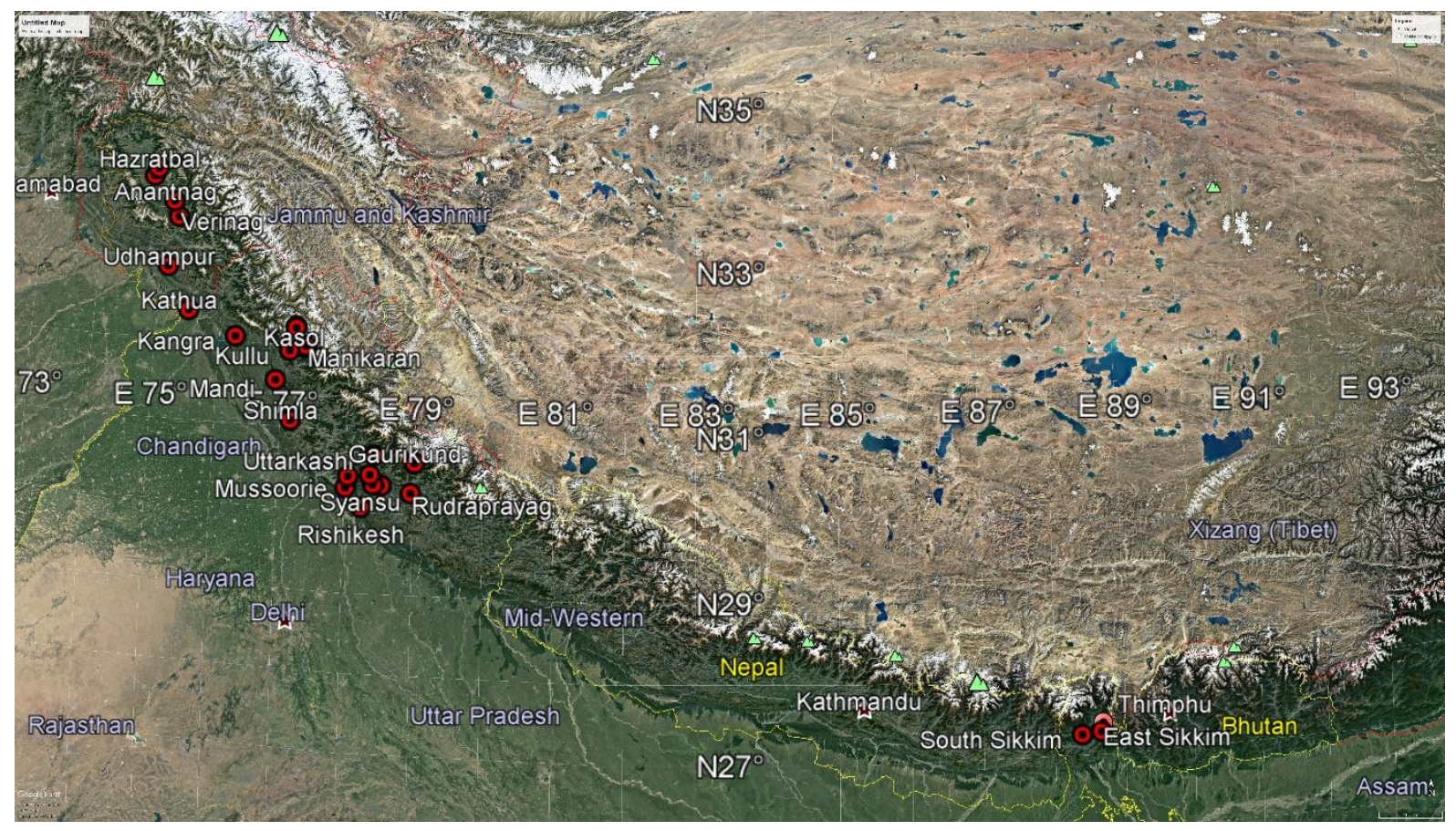

Figure 03: Location of Potential Spring Region in Himalayas (source: author generated)

\section{Monthly Fluctuation in Water Discharge of the Springs}

The studies conducted on the relationship between rainfall and spring discharge capacity show that the quantity of spring discharge increases during or after the rainfall period. The spring discharge is maximum in months like June, July, August, and September and is least during dry months of March, April and May (Girish C.S. Negi and Varun 2004) (S. S. Rawat 2018).

\section{Monthly Tourist Footfall Trend in Himalayan Region}

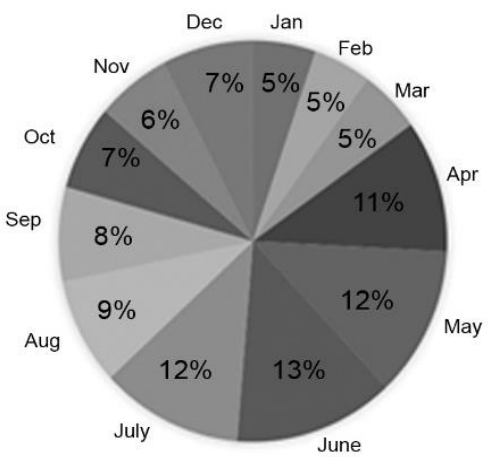

Himachal Pradesh

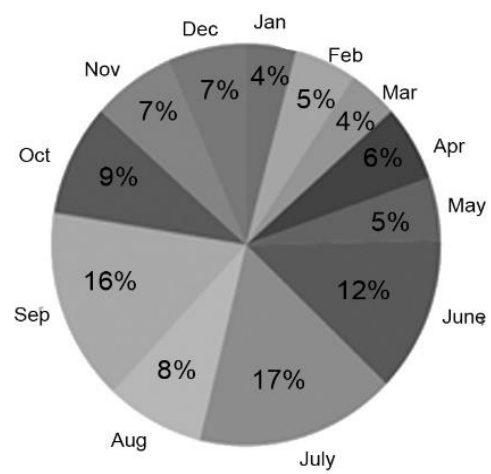

Uttarakhand

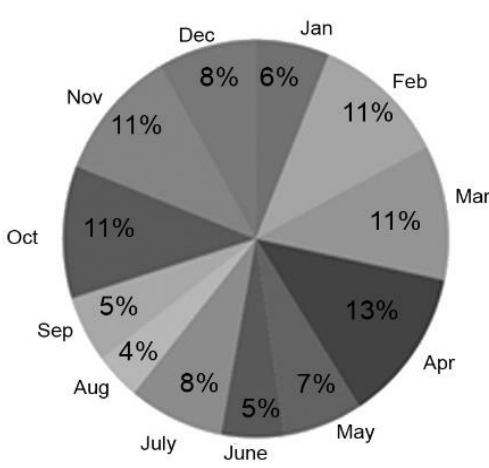

Sikkim

Figure04: Month wise tourist footfall pattern for Himalayan states

(Source: data from Ministry of tourism- survey for Himachal Pradesh, Uttarakhand and Sikkim)

As per the reports from tourist survey of India for Himalayan region, the tourist footfall was more during the months of April, May, June, July and December.

\section{Study of Spring Water Quality}

The study results show that the spring water quality in Hazratbal, Srinagar outweighed the spring water quality in Kullu valley, Himachal Pradesh in parameters like Electrical Conductivity, TDS, Calcium, Chloride, Magnesium, Sulphate \& Nitrate content. The difference 
in spring water quality can be attributed to the fact that Himachal Pradesh has more Tourist footfall \& population than Srinagar subjecting the water resources available under stress.

Table 02: Water quality studies in Hazratbal Srinagar and Kullu valley, Himachal Prd.

\begin{tabular}{|l|c|c|c|}
\hline Parameters & $\begin{array}{c}\text { Observed rang of } \\
\text { samples } \\
\text { In Hazratbal, Srinagar }\end{array}$ & $\begin{array}{c}\text { Observed rang of samples } \\
\text { In Kullu valley, Himachal } \\
\text { Pradesh }\end{array}$ & $\begin{array}{c}\text { Desirable } \\
\text { Limit }\end{array}$ \\
\hline Ph & $6.7-11$ & $6.5-7.85$ & $6.5-8.5$ \\
\hline Conductivity (uS/cm) & $136-968$ & $41-1795$ & 750 \\
\hline Salinity $(\mathrm{mg} / \mathrm{l})$ & $62-452$ & --- & -- \\
\hline $\begin{array}{l}\text { Total Dissolved Solids } \\
\text { (mg/l) }\end{array}$ & $94-682$ & $25-1368$ & 600 \\
\hline Total alkalinity (mg/l) & $39-156$ & --- & 300 \\
\hline Chloride(mg/l) & $5-37$ & $18-393$ & 250 \\
\hline Total Hardness (mg/l) & $48-274$ & --- & 300 \\
\hline Calcium (mg/l) & $5-56$ & $10-114$ & 75 \\
\hline Magnesium (mg/l) & $1-42$ & $5-52$ & 30 \\
\hline Sulphate (mg/l) & $6-53$ & $4-134$ & 200 \\
\hline Iron (ug/l) & $0.008-3.503$ & -- & 300 \\
\hline Nitrate (ug/l) & $214-3844$ & $0-224000$ & 45000 \\
\hline
\end{tabular}

Source: Studies conducted by- (Adeela Hamid, 2018) and (Nandni Thakur, 2018

\section{Spring Water Tourism in Other Parts of The World}

The developing countries Germany, Austria, France, Romania, Czech Republic, Israel, Turkey, China, etc. are providing tourism on thermal spring with area-specific healing methods. (Boekstein 2014). These countries are not only utilizing springs for wellness tourism but also promoting its value in sightseeing, entertainment, and vacation complex.

The water management solutions in these regions are broadly done in two ways:

a. By reducing overexploitation of spring water. In this scenario, the judicious use of available water resources and recycling the spring water for irrigation and other purposes is preferred.

b. Adopting ground water management practices like artificial recharge of aquifers, recharge wells, induced infiltration of subsurface water.

\section{Results and Discussion}

From the above studies, it is quite clear that the quality and quantity of spring water largely depends upon the geological, hydro-geological, and topographical features of the Himalayan region along with its climate. The therapeutical properties of the spring water and its wide use in yoga, naturopathy, and Ayurveda make it a unique feature to be utilized for health tourism in India. There are millions of springs in the Himalayan region but only a few of them are sustainable throughout the year. The areas mentioned in table 1 show only number of discovered springs and their minimum to maximum yield throughout the year. These locations have the potential to be developed for ashrams and resorts based on spring water healing. The aquifers are mostly dried up in summer seasons and hence the spring discharge is functional only through glacial meltwater and the quantity reduces drastically. Areas lying in Sikkim and Shimla region have a fair scope of developing tourism but the water discharge is pretty low due to seepage losses. Similarly, in most of the areas, the resorts and ashrams may face a shortage of water and that will affect their business.

The peak months of maximum tourist footfall is around the summer period in the Himalayan region as these are the holiday period in many foreign countries. The other group might be the business class people who want to conduct meetings along with the leisure 
experience benefiting their health. The weather in the Himalayan region remains cool and favourable for tourists at this time so people like to visit. The spring water quality may get hindered because of the growing tourism in this area. An unplanned approach can result in disturbing the fragile ecosystems of the Himalayan region and even affect the spring recharge areas resulting in low water levels in aquifers. Hence, there is a need to figure out a road map for further development. Springwater tourism in other countries is mainly based on thermal springs and their application in wellness tourism is different in each country. In India, Ayurveda, naturopathy, and yoga are the unique selling feature for wellness tourism industries. Specially the Himalayan region, also known as Yoga bhumi (land of yoga) with its high spiritual values, tourists would like to come here and experience the same (Adarsh Aggarwal 2008).

\section{Strategies for Wellness Tourism Development}

To tackle problems like landslides, pollution, water shortage, disturbance in natural drainage, and destruction of natural resources and scenic beauty in the Himalayan region, MOEF has provided guidelines, action plans, and regulations for sustainable development in the Himalayan region. (Governance for sustaining Himalayan ecosystem n.d.). The text also covers the ecotourism policies, commercial tourism regulations, regulations for solid waste management, and building regulations as per the Himalayan context.

Following strategies can be implemented for a sustainable wellness tourism development:

The increasing population, topsoil erosion, erratic rainfall pattern, and unplanned urbanization deeply disturbs the catchments areas for spring. (Sandeep Tambe1 2012) (S. S. Rawat 2018) Therefore, developmental planning should be done after allocating natural resources and paying consideration to them.

The idea for developing health resorts and yoga ashrams is best suited to the areas lying in the Shivalik region. Because of comparatively lower altitudes, the oxygen content in the air is more so the tourists will not find difficulty in breathing. The chances of cloud burst and glacier burst are also very less compared to the higher altitudes and hence make it safer. Moreover, from the studies, the chances of spring water formation are more in foothills.

The water from these springs contributes to the various rivers in the Himalayan region and their therapeutical properties are imparted in the river water as well. Therefore, the construction of these resorts or any other kind of settlement can be planned to leave a $200 \mathrm{~m}$ margin from river edges. The provisions for waste management should also be dealt with utmost care to prevent groundwater from getting polluted.

The tourists' activities should be planned considering the existing landscape and lofty topography of the Himalayan regions. The mountains are snow-capped during the winter seasons and hence activities like ice skating, skiing, or any other sports activities which can be performed on snow can be considered while designing landscapes for tourists. Moreover, with the Himalayan thermal springs as energy, the rooms of these resorts can be kept warm without depending largely on any other active source during harsh winter seasons (Chauhan 2016). However, in Rohtang pass, NGT has exposed ban on commercial activities to stop environmental degradation.

The plantation palate of these resorts and yogic ashrams should be using indigenous varieties for their self-sustenance. The yogic ashrams and resorts can include therapeutical gardens, sensory gardens, vegetable gardens, and herbal gardens for their tourists. The design of these ashrams can be inspired by the vernacular architecture of the specific area. 


\section{Methods and Guidelines to Make Spring Water Sustainable}

The development agencies and ministries are stressing over recharging the water sources and aquifers in the Himalayan region. The reports by NITI aayog and MOEF have initiated spring water management programs to revive dying springs. The Dhara Vikas program in Sikkim, Swajal initiative in Uttarakhand, spring shed management in Meghalaya, etc. are examples that with proper techniques and planning, the capacity discharge of Himalayan springs can be increased (Governance for sustaining Himalayan ecosystem n.d.) (Dr. Akhilesh Gupta 2018)

The spring water quantity in this context can be enhanced with the help of following strategies:

- The spring water from spa, swimming pools, bath tubs etc can be treated on site and can be used for flushing or irrigation purposes. This process can be done both by creating grey water oasis or by chemical and mechanical treatment.

- The recharge zones serving the springs can be demarcated and mapped. These areas can be customised for watershed measure like bunds, trenches and ponds along the contour direction to improve spring discharge.

- The water from these springs can directly be channelized to the resorts as in Himalayan region, the seepage loss is very high.

- The spring water can also be stored in subsurface check dams in downward direction to obtain spring water from seepage losses. This water can be stored in reservoirs and can be supplied to the resorts through pipelines.

- The spring is a valuable resource hence it should be used judiciously. With the help of rainwater harvesting master plans for these resorts and ashrams, the water required for irrigation, cleaning and other purposes can be revived. This will help in lessening the burden and exploitation of the valuable spring water.

\section{Conclusion}

The study revealed that the perennial nature and quality of spring water is a major play in geological, topography, climate, and hydrogeological setting of the Himalayan region. The Himalayan spring water has proven healing effects on health and finds great application in Indian naturopathy, yoga, hydrotherapy, and Ayurveda which is the reason why tourists from all over the world would like to visit for leisure with health tourism experience. The paper has examined the potential locations for wellness tourism by analysing spring water availability in Himalayan regions. Furthermore, with proper planning and strategies discussed in the paper, environment and tourist friendly tourism in Himalayan context. Finally, with the help of suggested policies and guidelines, we can make the springs water sustainable.

\section{References}

1. Adarsh Aggarwal, Meenal Guglani, and Raj Kumar Goel. 2008. "Spiritual \& Yoga Tourism: A case study on experience of Foreign Tourists visiting Rishikesh, India." Health, Spiritual and Heritage Tourism 2-3.

2. Adarsh Kumar Aggarwal, Meenal Guglani and Dr. Raj Kumar Goel. 2008. "Spiritual \& Yoga Tourism: A case study on experience of Foreign Tourists visiting." Health, Spiritual and Heritage Tourism.

3. Adeela Hamid, Sami Ullah Bhat, Tanu Jindal, Inam Sabha and Showkat Hussain lone. 2018. "water quality monitoring ofsome freshwater springs in Hazratbal Tehsil, Srinagar, Kashmir, Himalaya."

4. Bhartarya, K.S. Valdiya and S.K. 1989. "Diminishing discharges of mountain springs in a part of Kumaun Himalaya." Current science 420.

5. Boekstein, Mark. 2014. From illness to wellness-has thermal spring health tourism. African Journal of Hospitality, Tourism and Leisure.

6. Chauhan, Arun Bhatia and Dr. B. C. 2016. "Geothermal Tourism Potential in Himachal Pradesh." Amity Research Journal of Tourism, Aviation and Hospitality 2-9.

7. 2006. Collection of tourism statistics for the state of Uttarakhand. Ministry of tourism. 
8. Dr. Akhilesh Gupta, Dr. Himanshu Kulkarni. 2018. Inventory and Revival of Springs in the. NITI Aayog.

9. Girish C.S. Negi and Varun. 2004. "Rainfall and spring discharge patterns in two small drainage catchents in the western Himalayan Mountains, India." The environmentalist.

10. n.d. Governance for sustaining Himalayan ecosystem. Ministry of Environment, Forest and Climate Change (MoEF\&CC), G.B. Pant National Institute of Himalayan Environment and.

11. 2013. Ground water brochure Kathua district, Jammu and Kashmir. Central ground water report.

12. n.d. Ground water brochure of Rudraprayag district, Uttarakhand. Central ground water board.

13. n.d. "ground water brochure of Uttarkashi district, Uttarakhand."

14. n.d. Ground water brochure Tehri Garhwal, Uttarakhand. Central ground water board.

15. 2013. Ground water information booklet Anantnag district, Jammu and Kashmir. Central ground water board.

16. 2013. Ground water information booklet Kangra district, Himachal Pradesh. Central ground water report.

17. n.d. Ground water information booklet Mandi, Himachal Pradesh. Central ground water report.

18. n.d. Ground water information booklet south district of Sikkim. Central ground water board.

19. n.d. Ground water information booklet, Badgam district, Jammu and Kashmir. Central ground water board.

20. 2013. Ground water information booklet, Kullu district, Himachal Pradesh. Central ground water report.

21. n.d. Ground water information brochure east district of Sikkim. Central ground water board.

22. n.d. Ground water information brochure Udhampur district, Jammu and Kashmir. Central ground water board.

23. 2014. Ground water scenario of Himalayan region, India. Central ground water report.

24. mantralay, AYUSH. n.d. https://main.ayush.gov.in/about-the-systems/sowa-rigpa/introductionsowa-

rigpa\#: :text=Sowa\%2DRigpa\%E2\%80\%9D\%20is\%20one\%20of,the\%20entire\%20Trans\%2 DHimalayan\%20region.

25. Nandni Thakur, Madhuri Rishi Diana, A. Shrama and Tirumalesh Keesari. 2018. "Quality of water resources in Kullu valley in Himachal Pradesh, India: perspective and prognosis."

26. Rao, K.S. n.d. "Natural Resource Management and A Recourse to Issues and Strategies." Natural Resource Management \& Development In Himalaya 5-10.

27. S. S. Rawat, P. G. Jose, S. P. Rai and N. Hakhoo. 2018. "SPRING SANCTUARY DEVELOPMENT: SUSTAINING WATER SECURITY IN THE HIMALAYAN REGION IN CHANGING CLIMATE." International Conference on "Water, Environment and Climate Change: Knowledge Sharing and Partnership". 6-8.

28. Sandeep Tambe1, Ghanashyam Kharel1, M. L. Arrawatia2, Himanshu Kulkarni3, Kaustubh Mahamuni3, andAnil K. Ganeriwala. 2012. "Reviving Dying Springs: Climate ChangeAdaptation Experiments From the Sikkim Himalaya." Mountain Research and Development (MRD).

29. April 2011- March 2012. Tourism survey for the state of Himachal Pradesh. Ministry of tourism. 30. 2012. "Tourism survey report for the state of Sikkim."

31. Valdiya, K.S. 2010. "Physiographic layout of Indian subcontinent." In The making of Indiageodynamic evolution, by KS Valdiya, 1-6. Springer. 